\title{
HINDCAST HURRICANE SWELL FOR THE COAST OF SOUTHERN CALIFORNIA
}

by

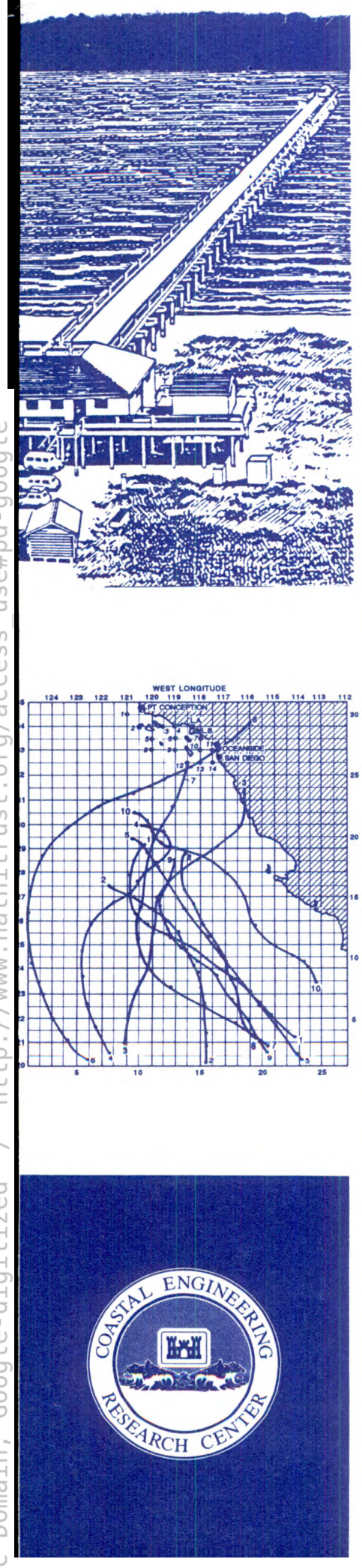

\author{
Barbara A. Tracy, Jon M. Huibertz \\ Coastal Engineering Research Center \\ DEPARTMENT OF THE ARMY \\ Waterways Experiment Station, Corps of Engineers \\ 3909 Halls Ferry Road, Vicksburg, Mississippi 39180-6199
}

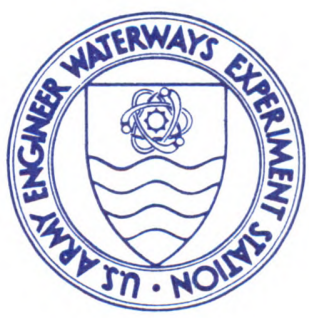

November 1990

Final Report

Approved For Public Release; Distribution Unlimited

ENVIRONMENTAL ENGINEERINC LIBRARY (138-78)

136 W. M. KECK LABORATOR'

California Institute of Technolog

Pasadena, California 91125 U.S

UNIVERSITY OF MICHIGAN

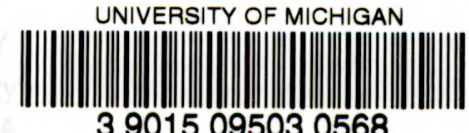

Prepared for DEPARTMENT OF THE ARMY

US Army Corps of Engineers

Washington, DC 20314-1000 